\title{
Salivary Gland
}

National Cancer Institute

\section{Source}

National Cancer Institute. Salivary Gland. NCI Thesaurus. Code C12426.

An exocrine gland that secretes saliva. Salivary glands are mostly located in and around the oral cavity. 